\title{
Fenomena Seleb Hijrah: Tendensi Ekslusivisme dan Kemunculan Kelompok Sosial Baru
}

\author{
Rahmi Nur Fitri \\ Pascasarjana Universitas Islam Negeri Sunan Kalijaga Yogyakarta \\ Email: rahminurfi396@gmail.com \\ Indah Rama Jayanti \\ Pascasarjana Universitas Islam Negeri Sunan Kalijaga Yogyakarta \\ Email: indahrama65@gmail.com
}

Naskah diterima: 19 November 2019 | Naskah disetujui: 19 Januari 2020

\begin{abstract}
Religious behavior nowadays has became a sector which has a lot of change. Modernity and globalization formed a society that was worried on their religious identity. This problem deliver to a new trend amongst young people and Indonesian celebrities. Campaigns of movement extensively spread on media social, self convertion to religious individuals also known as "seleb hijrah". The massive movement of hijrah lead by various groups that caused alteration the meaning of it and increased activities of religion commodification. Society today has liberation to select literature of hijrah concept that are available in the media. Media extention facilitate spreading of the existence of seleb hijrah which eventually form new communities such as "Kajian MuSaWaRah". Data obtain through social media, various video and articles discussing the same topic. This paper aims to scientifically explore and critically examine the phenomenon of seleb hijrah that have occurred among artists in recent years. Examine further the emergence of tendency of exclusivism in modern social circle. In addition, the article also explain the tendency of religious commodification in artists circle, in which called them selves with preacher. Nadirsyah Hosen said that hijrah activity amongst celebrities should not only be a popular trend to moving stage in seek of audiences. The majority of artists who are members of the group, innovate to maintain their existence in the public sphere.
\end{abstract}

Keywords: hijrah, artist, exclusivism, identity 


\begin{abstract}
Abstrak
Perilaku keagamaan masa kini telah menjadi bidang yang banyak mengalami perubahan. Modernitas dan globalisasi kemudian membentuk masyarakat yang terguncang akan identitas keagamaannya. Kekhawatiran ini kemudian menghasilkan tren baru di kalangan anak muda dan selebriti Indonesia. Kampanye gerakan untuk menjadi pribadi religius yang dilakoni para artis kemudian marak ditemukan di media sosial atau yang juga dikenal dengan seleb hijrah. Gerakan massif hijrah yang dilakukan oleh berbagai kalangan, menyebabkan terjadinya pergeseran makna hijrah serta meningkatnya aktivitas komodifikasi yang menjadikan agama sebagai obyeknya. Masyarakat dewasa ini bebas untuk memilih referensi hijrah dari sekian banyak sumber yang telah tersedia di media. Ekstensi media mempermudah penyebaran eksistensi artis hijrah yang akhirnya membentuk sebuah komunitas baru seperti Kajian MuSaWaRah. Data didapatkan melalui media sosial, berbagai video kajian serta artikel-artikel yang membahas topik yang sama. Tulisan ini bertujuan untuk menelusuri dan mengkritisi secara ilmiah fenomena seleb hijrah yang terjadi di kalangan artis beberapa tahun terakhir. Menelaah lebih jauh munculnya kecenderungan ekslusivisme kelompok sosial modern. Selain itu, artikel juga memaparkan terjadinya kecenderungan komodifikasi agama di dalam kelompok artis yang mulai mengidentifikasikan diri sebagai kelompok pendakwah. Mengutip tulisan Nadirsyah Hosen, aktivitas hijrah di kalangan artis seharusnya tidak hanya menjadi tren populer perpindahan panggung dalam mencari audiensi. Mayoritas artis yang tergabung ke dalam kelompok ini kemudian berinovasi untuk tetap mempertahankan eksistensi mereka di ranah publik.
\end{abstract}

Kata kunci: hijrah, artis, eksklusivisme, identitas

\title{
Pendahuluan
}

Dewasa ini, hijrah menjadi tren baru di kalangan anak muda dan para selebriti Indonesia. Beberapa tahun terakhir, gerakan hijrah di Indonesia menjadi fenomena baru yang dikampanyekan lewat media sosial. Instagram, facebook, dan youtube menjadi sarana paling diminati untuk menyalurkan gagasan ini. Januari 2018 penggunaan hashtag hijrah di instagram ditemukan sebanyak 1,7 juta kiriman, (DetikNews, 2019) dan pada awal Januari tahun berikutnya dapat ditemukan sebanyak 5,3 juta kiriman. Peningkatan sebanyak tiga kali lipat menandakan 2018 sebagai tahun menjamurnya gejala ini, atau tahun-tahun tren hijrah sebagai sebuah gerakan yang dilakukan secara massif.

Tren keagamaan menjadi produk entertainment telah terjadi sejak tahun 1990-an di beberapa negara Barat. Sebuah budaya populer yang menjadikan agama sebagai sebuah tren publik sejatinya bukan lagi suatu kasus yang baru terjadi. (Einstein, 2008: 8). Kristen Protestan mengusung istilah born-again Christian yang sejalan dengan 
pemaknaan kata hijrah. (Kailani dan Sunarwoto, 2019: 108). Di Indonesia, fenomena hijrah menjadi topik yang banyak dijadikan sorotan pemberitaan media pada saat banyaknya artis-artis pesohor yang memutuskan untuk menjadi pribadi yang lebih religius. Kasus para selebriti yang memutuskan berhijrah pernah ditulis oleh Kirana Nur Lyansari dengan menyoroti Branding Economic of Lifestyle, yang mana ketika seorang publik figur merubah gaya hidup yang sangat berbeda dari standarisasi dunia hiburan. Maka akan membentuk sebuah otoritas keagamaan baru dan juga munculnya kecenderungan menjadikan hijrah sebagai sebuah alat komodifikasi ekonomi. (Lyansari, 2018: 213).

Kasus maraknya artis hijrah yang kemudian mendadak menjadi pendakwah, atau yang dikenal juga dengan "ustaz seleb" juga terjadi di negeri Jiran, Malaysia. Rosli bin Mohammed menuliskan bahwa banyaknya artis hijrah menjadi konten dan tren baru bagi dunia pertelevisian Malaysia. Ia mengistilahkan dengan "he is a product by himself". (Mohammed, 2015: 89). Lofton (2011) juga menyebutkan bahwa profesi selebriti adalah sebuah pilihan yang mengharuskan diri mereka diakuisisi untuk dijadikan sebuah komoditas. Wajar saja banyak yang menyoroti aktivitas para artis pasca memutuskan untuk hijrah. Sebagaimana diketahui, sebelum memutuskan hijrah mereka adalah a product by himself, berbagai pertanyaan setelah itu bermunculan apakah mereka akan meninggalkan industri yang membesarkan nama mereka atau berinovasi dengan apa yang tengah mereka lakukan. Sedangkan secara eksplisit mereka telah bergeser dari lifestyle seorang publik figure atau artis yang identik dengan gaya hidup bebas dan glamor. Hakikatnya selebriti yang memilih untuk hijrah membutuhkan komunal baru agar lebih diterima.

Berbagai karya ilmiah yang mengangkat fenomena seleb hijrah, mayoritas mengaitkan dengan komodifikasi agama seperti economic branding. Tetapi tidak ada yang mengkaji lebih dalam mengenai kecenderungan seleb hijrah sebagai sebuah fenomena baru dari lahirnya komunitas kelompok sosial modern baru yang bersifat eksklusif. Hakikatnya antara eklusivisme dan komodifikasi agama yang terjadi di ruang lingkup para artis ini tidak bisa dipisahkan sama sekali. Konversi diri yang terjadi kepada mereka yang berprofesi sebagai selebriti menimbulkan kebingungan, yang mana memilih meninggalkan dunia hiburan sepenuhnya atau tetap bertahan dan eksis di hadapan publik dengan “wajah baru”. Pertanyaan ini kemudian seakan terjawab dengan 
kemunculan komunitas yang menaungi para artis yang memilih untuk hijrah. Satu di antara kelompok kajian yang didominasi oleh para selebriti ialah Kajian Muda Sakinah Mawaddah Warahmah (MuSaWaRah). ${ }^{1}$

Komunitas pengajian Musawarah terdiri dari para artis kondang tanah air, mereka adalah Teuku Wisnu, Shireen Sungkar, Zaskia Sungkar, Irwansyah, Jihan Fahira, Primus, Mario Irwinsyah, Arie Untung, Fenita Arie, Ricky Harun, Herfiza Novianti, Ifan Seventeen, Dimas Seto, Dhini Aminarti, Tommy Kurniawan, Virgoun, Sahrul Gunawan, Dude Harlino, Alyssa Soebandono, Tika Ramlan, dan masih banyak lagi. (Instagram Kajian MuSaWaRah, https://www.instagram.com/kajianmusawarah/). Kemunculan para artis hijrah kemudian menjadi simbol baru dalam pemaknaan hijrah itu sendiri, baik bagi para selebriti lain, dan juga bagi para penggemar mereka. Berdasarkan kepada ilmu psikologi, nama atau simbol tertentu mampu memberikan pengaruh bahkan sugesti kepada seseorang. (Ibrohim, 2016: 72). Tidak jarang ditemukan bahwa para publik figur seringkali dijadikan sebagai role model bagi sebagian orang dalam kehidupan sehari-hari. Untuk menunjukkan keseharian mereka yang baru, para selebriti menggunakan cyberspace untuk terus berkomunikasi dengan penggemar. (Annisa, 2018: 40).

Representasi kolektif yang diperkenalkan oleh Durkheim sejalan dengan kemunculan komunitas kajian para selebriti ini, yang mana pengalaman spiritualitas yang dibangun menjadi properti kolektif yang melandasi terbentuknya suatu kelompok sosial baru yang keseluruhan anggotanya diisi oleh para artis. (Scott, 2013: 51). Anggota yang hanya terdiri dari para artis inilah yang kemudian mengindikasikan adanya kecenderungan eksklusif di dalam kelompok mereka. Pratt (2007) dalam tulisannya menyebutkan bahwa paradigma dari eksklusif terbagi ke dalam tiga tipe, pertama terbuka, kedua tertutup, dan terakhir kelompok eksklusif yang ekstrem. Komunitas kajian Musawarah sebagai kelompok seleb hijrah di dalam kasus ini berimplikasi kepada jenis yang pertama yaitu kelompok sosial yang terbuka. Hal ini dikarenakan sebagian besar kajian yang diadakan terbuka untuk masyarakat umum, tetapi tidak sembarangan orang yang bisa bergabung menjadi anggota kajian.

\footnotetext{
${ }^{1}$ Kajian MuSaWaRah adalah akronim dari Muda Sakinah Mawaddah Warahmah, penulis awal disesuaikan dengan nama komunitas yang tercantum pada akun instagram @kajianmusawarah. Selanjutnya akan ditulis "Kajian Musawarah" guna memudahkan dan menghindari kesalahan dalam penulisan.
} 
Adapun pertanyaan-pertanyaan yang ingin dijawab di dalam tulisan ini, pertama bagaimana para artis yang memilih untuk hijrah memaknai proses atau arti dari kata hijrah itu sendiri. Kedua seberapa jauh tendensi ekslusivisme kelompok yang dihadirkan di dalam kelompok kajian Musawarah. Pertanyaan-pertanyaan tersebut ditelaah melalui pendekatan fenomenologi, yang mana tren hijrah dipahami dengan lebih terikat kepada nilai-nilai keagamaan yang dipercayai dan yang dimiliki oleh para pengikut agama yang ada, yang di sini diartikan dengan keberadaan kelompok kajian Musawarah (Abdullah, 1996: 12). Berdasarkan kepada persoalan di atas dapat diketahui bahwa fenomena hijrah yang sedang marak terjadi di tanah air, lebih dari permasalan komodifikasi dan otoritas keagamaan. Tren ini kemudian juga melahirkan suatu fakta sosial baru di tengah-tengah masyarakat.

\section{Eksklusivisme dan Kelompok Sosial Baru}

Perbincangan seputar eksklusivisme tidak pernah lepas dari persoalan teologi. Mayoritas tulisan-tulisan ilmiah menyandingkan konsep ini dengan persoalan keberagamaan. Padahal senyatanya urusan eksklusif atau inklusif selalu berawal dari kelompok sosial yang merasa memiliki kesamaan-kesamaan, sehingga tidak mungkin untuk tidak adanya ketimpangan atau kecenderungan dari suatu kelompok masyarakat yang memiliki keyakinan yang sama tetapi berbeda kelas sosial. Perbedaan lingkar sosial, keinginan untuk tetap memiliki kejelasan identitas dan status dalam struktur sosial, menjadi faktor yang mendukung dalam proses mempertahankan eksistensi di ruang publik. (Pratt, 2007: 8).

Terminologi eksklusif menurut situs daring Cambridge Dictionary diterjemahkan dengan "limited to only one person or group of people". Dugaan kecenderungan adanya sifat eksklusif dalam kajian Musawarah, yang mana dikenal secara luas sebagai sebuah kelompok kajian keagamaan, sama sekali tidak tanpa alasan atau hanya asumsi belaka. Merujuk kepada pengertian di atas dan dikaitkan dengan anggota kajian yang harus berasal dari publik figur atau artis, adalah sebuah fakta yang mengindikasikan adanya sifat-sifat eksklusif dalam kelompok ini.

Munculnya kelompok kajian para artis di bawah satu komunitas, menjadi alasan mereka untuk tampil dengan nyata di ruang publik. Perasaan aman dan lebih percaya diri merupakan representasi dari realitas hadirnya kelompok Kajian Musawarah sebagai 
sebuah fenomena hadirnya kelompok sosial baru di tengah masyarakat. Komunitas ini sama sekali tidak menyebutkan secara eksplisit kriteria untuk menjadi anggota kajian. Tetapi melihat berbagai postingan media sosial, mengisyaratkan bahwa syarat utama untuk menjadi anggota adalah mereka yang berprofesi sebagai publik figur. Fakta inilah yang menjadi landasan terdapatnya tendensi munculnya kelompok sosial baru di antara para artis yang memilih hijrah, yang mana juga bersifat ekslusif. (Youtube channel AlMuwatta, https://www.youtube.com/watch?v=F5ZTsGdBRnI: 2019).

Meski demikian, merujuk kepada paradigma yang diungkapkan Pratt, keberadaan kelompok artis ini tergolong kepada kelompok eksklusif yang terbuka. Terdapat beberapa alasan yang menjadikan komunitas ini tidak termasuk ke dalam kategori tertutup maupun ekstrem. Pertama, melakukan interaksi dengan mereka yang memiliki perbedaan, dalam hal ini lingkungan sosial. Pelaksanaan pengajian rutin yang dilakukan kajian Musawarah adalah sebagai bentuk interaksi yang didasarkan kepada persamaan dalam mencari ilmu agama, tetapi tidak dalam hal lingkar sosial yang lebih erat. Kedua, adanya pikiran rasional mengenai kebutuhan ekonomi. Sebagaimana diketahui bahwa selebriti yang memilih untuk hijrah akan melakukan branding berbagai produk-produk baru atas namanya. Realitas ini sebagai bukti bahwa mereka tidak bisa sepenuhnya tertutup. Alasan ketiga yang mengindikasikan suatu kelompok memiliki kecenderungan eksklusif adalah terkait dengan teori identitas subkultur, yang mana terjalinnya keterikatan dalam membangun realitas sosial tidak didasarkan kepada setiap orang yang melakukan kontak dengan mereka, melainkan merujuk kepada kelompok yang memberikan standar evaluasi perilaku yang sama. (Trinitapoli, 2007: 454).

Kehadiran kajian Musawarah sebagai sebuah kelompok sosial baru di antara para artis menimbulkan berbagai persoalan yang kemudian banyak dikaji oleh para pengamat sosial. Komunitas ini seakan sedang mencoba mempertahankan identitas sosial mereka sebagai seorang publik figur, baik itu di tengah-tengah masyarakat, dunia hiburan, dan juga media sosial yang memiliki pengaruh yang sangat besar dewasa ini. Wicandra (2006) mengutip Hall, yang mana ia mendefenisikan proses dari identifikasi diri sebagai sesuatu yang dinamis yang terbentuk dan mengikuti situasi individu yang terlibat. Ia menyimpulkan bahwa pada dasarnya manusia sebagai makhluk sosial tidak bisa terlepas dari upaya untuk merepresentasikan dirinya dengan sedemikian rupa di lingkungan sosial. Para selebriti yang memilih hijrah berawal dari proses pencarian 
identitas yang kemudian diikuti oleh artis lainnya. Berawal dari memiliki keresahan yang sama, yang mana biasanya mereka berkomentar mengenai konflik dan kekosongan internal di dalam diri, para artis ini kemudian mengidentifikasikan diri mereka dengan “jalan hijrah". Berawal dari Teuku Wisnu, Dimas Seto, Irwansyah, dan terus diikuti oleh artis lainnya, bentuk identifikasi baru para artis ini berlanjut ke dalam bentuk komunitas yang mereka namai dengan Kajian Musawarah.

\section{Pemaknaan Hijrah di Kalangan Artis}

Fenomena hijrah di kalangan artis sebenarnya sudah muncul sejak lama, dimulai dari kalangan musisi seperti Gito Rollies dan Sakti 'Sheila On 7' yang terjadi di awal tahun 2000-an. Mereka mulai mendalami ilmu agama dan berdakwah, serta menjadikan musik yang telah membesarkan nama mereka sebagai media penyebaran ke-Islaman. Meskipun perubahan yang mereka lakukan secara substansial adalah hijrah, tapi masyarakat dan media pada masa itu tidak pernah menyebutnya demikian. Penyebutan dan tren kata hijrah sebagai representasi perubahan secara spiritualitas seperti yang dilakukan para musisi di atas, baru mendapatkan banyak perhatian baik dari kalangan akademisi, dunia hiburan, dan masyarakat luas beberapa tahun belakangan ini. (DetikNews, 2019). Pasca banyaknya artis yang memutuskan untuk hijrah, terminologi ini kemudian tidak hanya terjadi di ruang lingkup selebriti Indonesia, melainkan juga banyak terjadi di kalangan anak muda, seperti kemunculan komunitas Pemuda Hijrah atau Shift yang digagas oleh Ustaz Hanan Attaki.

Secara historis, hijrah diterjemahkan kepada makna yang merujuk perpindahan ke wilayah lain. Ia lebih ditujukan kepada berpindah dalam artian tempat dari pada makna spiritualitas. Hijrah di dalam Al Qur'an diindikasikan kepada bermigrasi, meninggalkan atau menarik diri, guna menunjukkan hijrah para Nabi. (Esposito, 2001: 156). Mayoritas ulama berpendapat dengan memaknai hijrah sebagai sebuah perpindahan fisik. Adapun pemaknaan hijrah guna mendekatkan diri kepada kebiasaan yang baik serta meninggalkan perbuatan yang menjauhkan diri dari kebenaran adalah hijrah yang ditujukan untuk para sufi. (Jazuli, 2006: 23). Sedangkan makna hijrah yang dimaknai dewasa ini memiliki kemiripan dengan born-again Christian yang terjadi di kalangan umat Kristen Protestan. (Kailani dan Sunarwoto, 2019: 108). 
Perubahan yang banyak terjadi di kalangan para artis yang memutuskan untuk berhijrah memunculkan interpretasi tersendiri. Hal tersebut menyebabkan kata hijrah semakin eksis ketika direalisasikan dan diimplementasikan oleh kalangan artis. Profesi publik figur memudahkan mereka untuk mendapatkan tempat di hati penonton. Bahkan tidak jarang perubahan baru ini mendapatkan respon positif dari masyarakat. Sejumlah selebriti yang terkenal karena aksi hijrah, di antaranya adalah Teuku Wisnu, Shireen Sungkar, Zaskia Sungkar, Irwansyah, Fenita Arie dan masih banyak lagi nama-nama artis yang masuk ke dalam daftar 'seleb hijrah'.

Ansori (2019) menyebutkan bahwa secara terminologi dakwah tidak hanya dilakukan dengan ceramah di atas mimbar, akan tetapi dakwah juga bisa dilakukan melalui aksi nyata yang lebih dikenal dengan pemberdayaan masyarakat yang mengimplementasikan nilai-nilai dakwah Islam guna mewujudkan masyarakat yang Islami dan sejahtera. Pemaknaan inilah yang sejalan dengan semangat para artis dalam meniatkan hijrahnya untuk berdakwah dengan saling mengajak teman yang satu profesi. Hijrahnya para artis disebabkan atas kesadaran individu yang dipengaruhi oleh sebuah peristiwa yang berkaitan dengan situasi yang sedang terjadi, sehingga membutuhkan ketenangan dan solusi untuk mengatasinya. (Lyansari, 2018: 211-232) dan hal tersebut mendapat respon positif dari masyarakat yang kemudian berdampak kepada pemberian gelar ustadz/ustadzah pada selebriti hijrah.

Salah seorang pimpinan Syuriah PCI Nahdatul Ulama, yaitu Nadirsyah Hosen mencoba menyikapi fenomena hijrah di kalangan artis melalui postingan di akun twitternya@na_dirs tertanggal 27 Mei 2018, ia membuat utasan seputar fenomena hijrahnya para artis ke dalam sepuluh cuitan, di antara tulisannya tersebut ia mengungkapkan:

Jangan sampai hijrah hanya jadi trend populer saja. Misalnya, para artis yg hijrah itu bagus, tapi jgn sampai itu hanya jadi "panggung" mereka berikutnya. Semula dari panggung sinetron dan musik, skr jadi panggung dakwah.

Makanya Rasul pun mengingatkan dalam hadits terkenal saat hijrah, yaitu setiap amal tergantung niatnya. Anda mau hijrah niatnya apa? Apa nyari panggung dakwah yg lg trend karena gak laku lagi di panggung yg lama? Sdh sampai mana kapasitas ilmu \& pribadi sampai berani dakwah?

Nadirsyah Hosen menerangkan bahwa Islam hakikatnya bersifat lentur dan fleksibel, tanpa membatasi seseorang untuk mengenal Islam lebih dalam. Sehingga apapun profesi yang ditekuni bukanlah penghalang bagi seseorang untuk 
meningkatkan kualitas spiritualitasnya. Melihat fenomena artis hijrah saat ini, muncul kekhawatiran yang mana mereka kemudian akan lebih dikenal dan terkenal sebagai pesohornya para artis yang baru mengenal hijrah. Mayoritas dari seleb hijrah memilih untuk memundurkan diri dari dunia hiburan dan beralih profesi menjadi ustaz atau pembicara dalam kajian-kajian ke-Islaman di masjid-masjid maupun acara dakwah di stasiun TV. Qasim Zaman (2009) dalam Islam ad Modernity mengistilahkan fenomena ini dengan "storytellers and popular preachers", yang mana pada kemunculan artis hijrah sebagai pendakwah mampu menggeser fondasi otoritas keagamaan yang sebelumnya selalu merujuk kepada ulama. (Masud, Salvatore \& Bruinessen (ed.), 2009: 211).

Salah satu contoh artis memiliki karier yang bagus di dunia hiburan dan kemudian memilih untuk hijrah ialah Fenita Arie (istri Arie Untung). Ia merupakan seorang presenter infotainment ternama di salah satu stasiun televisi swasta yang memutuskan untuk berhijab pada awal tahun 2018. Contoh publik figur perempuan lainnya yang juga memutuskan untuk hijrah adalah Chacha Frederica. Sebelum memutuskan hijrah ia banyak membintangi berbagai sinetron di pertelevisian Indonesia. Ia mengungkapkan bahwa alasannya untuk berhijab bukan hanya sebatas mematuhi aturan agama saja, baginya menggunakan kerudung adalah sebuah representasi dalam menunjukkan kebebasan, hak, dan kemampuan seseorang. Para artis yang memilih untuk hijrah ini kemudian bertransformasi dari segi sikap dan lifestyle yang lebih Islam dalam kehidupan sehari-hari.

Tren hijrah yang terjadi di kalangan artis menjadikan kelompok Kajian Musawarah semakin memiliki banyak anggota yang berasal dari kalangan publik figur. Kelompok baru artis hijrah ini secara tidak langsung membuat sebuah "standarisasi" baru dalam pemaknaan hijrah di kalangan selebriti. Ustaz atau tokoh-tokoh agama tidak lagi menjadi referensi utama untuk selebriti yang baru memilih untuk memahami agama secara lebih dalam. Mereka tetap berpedoman dan meminta pemahaman ilmu kepada para ulama secara bersama-sama untuk mendalami Islam. Hal ini bisa dilihat dari banyaknya kajian yang diselenggarakan oleh Kajian Musawarah yang memanggil ustaz kondang, seperti Ustaz Adi Hidayat dan Ustaz Abdul Somad. Tetapi tetap saja kehadiran kelompok kajian Musawarah ini kemudian menjadi fenomena dan rujukan baru bagi kalangan artis dan anak muda untuk berhijrah. Banyak ditemukan di antara 
para selebriti hijrah ini kemudian diundang ke berbagai acara-acara motivasi, guna menceritakan kisah perjalanan mereka hingga sampai ke tahap memilih untuk berhijrah. Sejatinya fenomena ini juga merujuk kepada masyarakat Muslim yang lebih tertarik dengan kisah inspiratif mereka. Selain itu biasanya pesan-pesan yang disampaikan terasa lebih fresh karena sesuai dengan realitas sosial. (Echchaibi, 2011: 27).

Kajian MuSaWaRah ini diikuti oleh Arie Untung yang berhijrah bersama sang istri yaitu Fenita Arie diawali dengan ikut serta dalam kajian-kajian dakwah. Dalam kajian tersebut ada kalimat yang menjadi simbol mereka "Hijrah itu berjama'ah, jangan sendiri-sendiri”. (Instagram @ ariekuntung kiriman tanggal 23 Desember 2018). Suami dari Fenita Arie ini menjelaskan arti dari kalimat tersebut "bahwa hijrah bersama temanteman akan lebih mudah dijalani daripada sendiri. Keistiqamahan akan muncul secara alami jika dalam kehidupan sehari-hari kita juga berkumpul dengan sahabat yang beriman". (KumparanHITS, 2019).

Kajian MuSaWaRah memberi kesan menonjol atas ke-eksklusifan kelompok, karena beranggotakan hanya sebatas dari kalangan artis dan kaum elit saja. Selain itu berbagai bisnis dan produk yang mereka keluarkan, mayoritas ditujukan bagi pasar kelas menengah ke atas. Ustadz Adi Hidayat mengatakan dalam suatu kajian "Kajian Musawarah ini memang terkhususkan untuk kalangan publik figur sehingga terbatas untuk bisa memperbaiki diri, tapi terekam untuk publik agar mereka juga bisa belajar". (Youtube Channel unggahan tanggal 31 Januari 2019). Dari pernyataan tersebut dapat dimaknai dengan pembatasan diri dari orang-orang selain artis. Mereka yang senior atau lebih dulu dalam berhijrah mulai mengajak artis lainnya untuk mengikuti apa yang sedang dilakukannya. Namun, jika dilihat dari pemberitaan di beberapa media, para artis hijrah sama sekali tidak bisa terlepas dari pergaulan artis, sehingga mereka membentuk sebuah kelompok sosial baru yang bisa menaungi mereka dalam proses hijrah.

\section{Kajian Dakwah dan Identitas Komunitas}

Kajian MuSaWaRah merupakan sebuah komunitas pengajian yang diinisiasikan oleh beberapa artis hijrah, seperti Teuku Wisnu, Arie Untung dan Dimas Seto. (Idn Times: 2019). Meski tergolong kepada sebuah komunitas, keanggotaannya bersifat eksklusif dan tertutup, yang mana hanya artis serta publik figur saja yang menjadi anggota. Kajian MuSaWaRah ini berdiri pada tahun 2011 atas dasar keinginan dari hati 
para artis yang ingin meninggalkan kehidupan lama ke kehidupan baru yang lebih baik dan mengenal lebih dalam tentang ajaran agama atau yang lebih populer dengan sebutan hijrah. Para artis yang ikut bergabung dalam Kajian MuSaWaRah adalah Irwansyah, Teuku Wisnu, Shiren Sungkar, Zaskia Sungkar, Arie Untung, Jihan Fahira, Primus, Mario Irwinsyah, Fenita Arie, Ricky Harun, Herfiza Novianti, Ifan Seventeen, Dimas Seto, Dhini Aminarti, Tommy Kurniawan, Virgoun, Sahrul Gunawan, Dude Harlino, Alyssa Soebandono, Tika Ramlan, dan masih banyak lagi.

Mereka berdakwah dimulai dari masjid ke masjid di beberapa daerah maupun kota. Kemudian mereka juga memanfaatkan media sebagai wadah sharing seputar pengalaman hijrah para artis dan pengajian-pengajian dari para ustaz, seperti yang diunggah dalam channel youtube "Kajian Musawarah" dan akun instagram "Kajian Musawarah". Materi atau pesan dakwah yang disampaikan kelompok Kajian MuSaWaRah yaitu mengenai keseluruhan ajaran Islam yang bersumber dari Al-Quran dan Hadits yang masih berkaitan dengan kehidupan sehari-hari, tidak lain yaitu tentang ajaran fiqh. Para selebriti yang tergabung dalam kelompok kajian tersebut mendeskripsikan Kajian Musawarah ini sebagai ukhuwah dalam keberagaman, tempat berkumpul dan berbagi sahabat-sahabat pekerja seni, sharing, caring dan saling support dalam keistiqomahan. Belajar bersama ulama-ulama yang peduli dengan kemajuan Muslim di Indonesia. (Channel youtube "Kajian Musawarah"). Mereka lebih sering memberi konten dengan tema pengalaman dan proses hijrah mereka sebagai kelompok hijrah artis.

Fenomena selebriti hijrah yang kemudian juga menjadi "pendakwah" sejatinya menggeser otoritas keberagaamaan. Hal ini dikarenakan ulama yang biasanya lebih berpaham tradisionalis dalam menghadapi modernitas. Kemajuan teknologi dan juga akses ke-Islaman yang semakin luas menjadi tantangan baru bagi umat Islam. (Masud, Salvatore \& Bruinessen (ed.), 2009: 216). Gaya hidup para artis yang fleksibel dan modern lebih banyak disenangi oleh masyarakat. Terlebih jika artis yang hijrah tersebut adalah idola, maka referensi untuk melihat Islam itu akan menjadi lebih mudah untuk bergeser. Selain itu, intensitas seorang publik figure dalam berinteraksi dengan sosial media jauh lebih tinggi.

Dilansir dari berbagai unggahan yang terdapat di berbagai sosial media, terdapat dua jenis pengajian yang diadakan oleh kelompok Kajian Musawarah ini. Pertama yaitu 
pengajian tertutup yang hanya dihadiri oleh para artis saja, kedua yaitu pengajian terbuka yang bisa diikuti oleh masyarakat luas. Pada permulaan tahun 2019, Raffi Ahmad menfasilitasi Kajian Musawarah untuk melangsungkan pengajian di rumahnya, dan kegiatan ini dihadiri dari kelompok artis saja. (Youtube "The Sungkar Family" unggahan tanggal 21 Januari 2019). Sedangkan untuk kajian dakwah yang terbuka untuk umum biasanya diadakan di kompleks Masjid Raya Kebayoran Residences. (Instagram @kajianmusawarah: https://www.instagram.com/kajianmusawarah/). Selain ikut aktif dalam ruang dakwah, yaitu dengan mengadakan berbagai acara ke-Islaman, kelompok ini tampak aktif menyuarakan berbagai isu-isu yang tengah terjadi di masyarakat, seperti zero waste, penyaluran bantuan untuk daerah terdampak asap, ikut melaksanakan kegiatan berqurban, dan kegiatan-kegiatan keagamaan dan sosial lainnya.

Hal menarik lainnya adalah, identitas yang dihadirkan di tengah-tengah masyarakat sangat persuasif. Konsep tentang identitas kelompok merupakan salah satu teori perkembangan sosial yang merujuk pada pengakuan terhadap makna keanggotaan atau makna kebersamaan. (Dwijayanto, 2020). Seperti ajakan-ajakan yang mengarah kepada dakwah, kegiatan sosial dan sebagainya. Mereka memiliki tujuan yang sama dengan membangun interaksi positif sesama anggota untuk kepentingan bersama yaitu berhijrah. Tidak bisa diingkari bahwa berbagai kegiatan yang diadakan oleh kelompok kajian Musawarah adalah bentuk positif dari sebuah komunitas. Namun, ketika munculnya berbagai pernyataan bahwa anggota dari kelompok ini adalah para artis yang memilih untuk hijrah, terdapat tendensi ekslusivitas sebuah kelompok di dalamnya. (Ubaidillah, 2000: 3).

Kelompok kelas yang mereka tawarkan sangat jelas, karena mereka memiliki situasi kelas yang sama dalam mencari kesempatan untuk memperoleh jati diri dan menentukan kehidupan ekstern yang dapat dimanfaatkan di pasaran. Sistem kelas adalah konsep yang dperkenalkan oleh Marx, kelas sebagai kategori analitis inilah yang menyebabkan dinamika masyarakat modern. (Basis, 2019). Dari pernyataan Marx di atas semakin terlihat pada saat para artis hijrah ini memasarkan berbagai brand, yang mana target pasarnya ialah kelas menengah ke atas dan memberikan identitas kelompok baru. Fakta ini adalah sebagai kelanjutan dari latar belakang kehidupan mereka sebelum memutuskan untuk hijrah. 


\section{Kelompok Sebagai Sarana Hijrah dan Bisnis}

Ketika hijrah di kalangan artis menjadi tren, yang kemudian diikuti dengan gaya berpakaian yang juga berubah, kemudian hal tersebut dimanfaatkan oleh sejumlah artis tanah air untuk membangun bisnis busana Muslim. Berawal dari kebutuhan mereka untuk memenuhi pakaian hijrah, mereka juga berbagi ide gaya berpakaian atau yang biasa disebut outfit of the day (ootd) melalui akun instagram mereka. Seperti Zaskia Adya Mecca dengan cloth line-nya yang bernama Meccanism, kemudian Shireen Sungkar dengan Gerai Hawa-nya dan masih banyak lagi. Mulai dari gaya berpakaian sehari-hari untuk perempuan, laki-laki dan anak-anak sampai pakaian formal dan gaun pengantin juga dipasarkan. Rata-rata artis yang tergabung dalam komunitas Musawarah memulai bisnis yang mereka geluti ketika mereka memutuskan untuk berhijrah.

Para artis yang tergabung dalam komunitas Musawarah ini selain berfokus untuk hijrah, kebanyakan dari mereka meninggalkan dunia hiburan kemudian beralih mengurusi bisnis yang mereka geluti. Untuk mempertahankan eksistensi yang telah dimiliki sebelumnya, mereka memanfaatkan media sosial sebagai sarananya. Tidak hanya fashion, bisnis mereka juga merambah ke bidang kuliner, yang lebih dikenal dengan cake artis atau kue kekinian. Para artis ini memanfaatkan kepopuleritasan yang tentu saja langsung menyedot perhatian publik. Bisnis kue kekinian ini memiliki kemiripan dalam konsep, promosi, kemasan, cita rasa yang ditawarkan, sampai pada pemilihan nama untuk kue kekinian mereka yang menyebar ke penjuru Indonesia. Untuk proses marketing, acapkali teman-teman satu komunitas saling mempromosikan produk yang lainnya di akun sosial media pribadi mereka.

Berawal dari tahun 2014, Teuku Wisnu membuka bisnis oleh-oleh kue kekinian di Malang dengan nama Malang Strudel. (Hipwee.com, 2019). Kemudian disusul oleh Dude Herlino dengan Jogja Scrummy-nya. Jogja dipilih Dude Herlino sebagai kota untuk memulai bisnis oleh-oleh kue nya karena Jogja memang dikenal sebagai kota wisata, bahkan Jogja Scrummy kini memiliki 4 gerai di Jogja. Pada awal kemunculannya kue-kue artis ini banyak digemari oleh sebagian masyarakat. Namun, secara perlahan konsumen mulai beralih lagi ke makanan-makanan khas daerah. Terdapat beberapa asumsi yang bisa diangkat dalam melihat kasus ini, pertama untuk ukuran harga, kue artis ini terbilang "cukup mahal" jika dibandingkan dengan kue-kue khas daerah lainnya. Kedua bahwa ukuran atau porsi yang ditawarkan terbilang cukup 
tidak sepadan dengan harga yang ditawarkan. Pandangan ini sejalan anggapan bahwa sasaran pasar dari para artis ini adalah kelompok kelas menengah ke atas.

Setelah bisnis kedua artis ini terlihat menjanjikan, kemudian artis-artis lain mengikuti jejak keduanya untuk mendirikan usaha yang sama di kota yang berbeda. Lebih dari 18 artis yang juga tergabung dalam komunitas MuSaWaRah ini terjun ke bisnis kue kekinian. Dengan penampilan kue yang sama, ternyata kue-kue para artis ini dinaungi oleh satu management yang sama yaitu Jannah Corp. Meskipun begitu, Zaskia Sungkar sebagai founder mengungkapkan bahwa tidak ada persaingan di dalamnya. "Kita cuma manusia biasa yang terkadang surprise dan sedih melihat diluar sana ada beberapa yang istilahnya tinggal "COPY-PASTE”. Tak perlu perjuangan awal mikirin ide, konsep hingga template, dan typical foto yang mungkin hampir sama yang telah kami creat." (Sentral Berita, 2017).

Selain itu, Jannah Corp juga menaungi bisnis tour and travel milik artis-artis yang tergabung dalam Kajian Musawarah. Karena minat travel masyarakat Indonesia semakin tinggi, maka bisnis travel juga tidak kalah menjanjikan di samping bisnis busana dan kue kekinian. Bahkan beberapa bisnis travel milik artis-artis seperti Zaskia Sungkar-Irwansyah, Ricky Harun, Syahrul Gunawan, Irfan Harun, dan Shireen Sungkar Teuku Wisnu juga gencar menawarkan jasa umrah. Mereka menawarkan fasilitas umrah kelas menengah ke atas yang mana mereka sebagai owner ikut serta dalam perjalanan umrah tersebut. Hal ini sebagai bentuk promosi yang menjanjikan dan menarik peminat.

Profesi baru sebagai pendakwah dan motivator, menjadikan beberapa artis mengisi berbagai acara kajian maupun bisnis. Komunitas kajian Musawarah juga menfasilitasi dalam pelaksanaan talk show mengenai bisnis yang langsung diisi oleh mereka sebagai pembicara. Sepasang suami istri artis seperti Teuku Wisnu dan Shireen Sungkar kerap kali mengisi talk show entrepreneurship dalam acara-acara keagamaan yang diadakan oleh komunitas mereka. Hal tersebut dikarenakan bisnis Teuku Wisnu dinilai memiliki branding yang kuat, baik dibidang fashion, kue kekinian maupun tour and travel.

Bisnis dalam Islam sebenarnya diperbolehkan, dalam Al-Qur'an dijelaskan melalui kata tijarah yang mencakup dua makna, yaitu: pertama, perniagaan secara umum mencakup perniagaan antara manusia dengan Allah seperti menjalankan perintah-Nya, menafkahkan sebagian rezekinya, maka itu adalah sebaik-baik perniagaan 
manusia dengan Allah. Kedua, perniagaan secara khusus yang berarti perdagangan ataupun jual beli antar manusia. (Fauzia, 2013: 7-8). Beberapa ayat Al-Qur'an menerangkan tentang diperbolehkannya jual beli, salah satunya terdapat dalam QS. AlBaqoroh ayat 275: :..... yang artinya, “Dan Allah menghalalkan jual-beli dan mengharamkan riba”. Maraknya tren hijrah dan juga sejalan dengan kemunculan berbagai bisnis yang diinisiasikan oleh artis hijrah, serta kemunculan mereka sebagai "storytellers and popular preachers" seolah mengindikasikan hijrah sebagai sebuah branding dari bisnis baru mereka.

\section{Kesimpulan}

Fenomena hijrah sudah menjadi tren baru di kalangan anak muda dan para selebriti Indonesia. Para artis berhijrah diawali dengan mengikuti kelompok kajian Islam. Satu di antara kelompok kajian yang didominasi oleh para selebritis ialah Kajian MuSaWaRah (Muda Sakinah Mawaddah Wa Rahmah). Komunitas ini terdiri dari para artis kondang tanah air, seperti Teuku Wisnu, Shireen Sungkar, Zaskia Sungkar, Irwansyah, Arie Untung, dan masih banyak lagi. Para artis hijrah ini meninggalkan dunia hiburan kemudian lebih berfokus pada kajian Islam dan bisnis yang mereka bangun setelah mereka hijrah. Kemudian dengan adanya Kajian Muswarah ini memunculkan pemaknaan ulang tentang hijrah bagi para artis. Kata hijrah semakin eksis ketika dilakukan oleh kalangan artis. Maka dari memberikan kesan menonjol atas keeksklusivan kelompok, karena hanya dikhususkan untuk kalangan public figur saja. Anggota kelompok yang hanya terdiri dari para artis mengindikasikan adanya tendensi eksklusif di dalamnnya. Selain itu berbagai produk dan bisnis yang dikeluarkan oleh selebriti hijrah ini memiliki sasaran pasar yang berasal dari kelompok kelas menengah ke atas.

\section{Referensi}

Annisa, Firly. "Hijrah Milenial: Antara Kesalehan dan Populism”. Jurnal Maarif, Vol. 13, No. 1, Juni 2018.

Ansori, Teguh. "Revitalisasi Dakwah Sebagai Paradigma Pemberdayaan Masyarakat". Muharrik: Jurnal Dakwah dan Sosial Vol. 2 No.1, 2019. 
Dwijayanto, Arik. "Managing Democracy in Malaysia: Identity, Minorities and Representation.” Jurnal ARISTO: Social, Politic, Humaniora Vol.8 No.1. 2020.

Esposito, John L. Ensiklopedi Oxford: Dunia Islam Modern. jilid 2, Bandung: Penerbit Mizan. 2001.

Fauzia, Ika Yunia. Etika Bisnis dalam Islam. Jakarta: Kencana Prenadamedia Grup. 2013.

Jazuli, Ahzami Samiun. Hijrah Dalam Pandangan Al-Qur'an. Jakarta: Gema Insani. 2006.

Juliawan, B. Hari. Mampukah Kelas Bertahan dalam Kepungan Identitas?. Yogyakarta: Majalah BASIS, No. 05-06 THN. 68. 2019.

Ibrohim, Busthomi. Memaknai Momentum Hijrah. Jurnal Ilmiah Pendidikan STUDIA DIDAKTIKA, Vol. 10 No. 2 Th 2016.

Echchaibi, Nabil. "From Audio Tape to Video Blogs: Delocalisation of Authority in Islam". Journal Nation and Nationalism, Vol. 17, No. 1, 2011.

Einstein, Mara. Brands of Faith: Marketing Religion in a Commercial Age, New York: Routledge. 2008.

Kailani, Najib dan Sunarwoto. "Televangelisme Islam Dalam Lanskap Otoritas Keagamaan Baru" dalam Ulama dan Negara Bangsa: Membaca Masa Depan Islam Politik di Indonesia, Yogyakarta: PusPIDeP. 2019.

Lyansari, Kirana Nur. Hijrah Celebrity: Creating New Religiosities, Branding Economics of Lifestyle in the Age of Muslim Mass Comsumption. Jurnal Studi Keislaman, Vol. 18, No. 2, Desember 2018.

Masud, Muhammad Khalid, Armando Salvatore dan Matin bvan Bruinessen, Islam and Modernity. Edinburgh: Edinburgh University Press. 2009.

Mohammed, Rosli bin. "The Impact of Character Branding Through Media: A Case Study of TV al-HIjrah's Ustaz Celebrity Programme”. Journal of Islamic Research, Vol. 9, No. 2, 2015.

Lofton, Kathryn. "Religion and the American Celebrity". Journal Social Compass, Vol. 58, No. 3, 2011.

Pratt, Douglas. "Exclusivism and Exclusivity: A Contemporary Theological Challenge." Journal Pacifica. October 2007. 
Scott, John. ed. Sosiologi: The Key Concept, terj. Tim Penerjemah Labsos FISIP UNSOED, Jakarta: Rajawali Pers. 2013.

Trinitapoli, Jenny. "Religious Exclusivism Among U.S Adolescents." Journal The Sociological Quarterly, Vol. 48, No. 3, 2007.

Ubaidillah, A dkk. Pendidikan Kewargaan Demokrasi, Ham, dan Masyarakat Madani. Jakarta: IAIN Jakarta Press. 2000.

Wicandra, Obed Bima. "Graffiti di Indonesia: Sebuah Politik Identitas ataukah Tren?." Jurnal Nirmana, Vol. 8, No, 2, Juli 2006.

\section{Internet}

DetikCom. Fenomena Hijrah di Kalangan Anak Muda. Diakses di laman https://news.detik.com/kolom/d-3840983/fenomena-hijrah-di-kalangan-anakmuda. 30 Januari 2018.

kumparanHITS. Kebahagian Arie Untung Melihat Fenomena Selebriti Hijrah. Diakses di laman https://kumparan.com/kumparanhits/kebahagiaan-arie-untung-melihatfenomena-selebriti-hijrah-1541752596163016260. 09 November 2018.

Hipwee.Com. Trend Baru! Deretan Artis yang Menggeluti Bisnis Kue. Diakses di laman https://www.hipwee.com/opini/tren-baru-deretan-30-artis-indonesia-yangmenggeluti-bisnis-kue-oleh-oleh-khas-kekinian/. 19 Juli 2017.

Sentral Berita, Zasia dan Irwansyah Ramaikan Wisata Kuliner Kota Medan: Cake Berbahan Pisang Barangan. diakses di laman https://sentralberita.com/2017/11/zascia-sungkar-irwansyah-ramaikan-kulinerdi-medan-cake-berbahan-dasar-pisang-barangan/. 19 November 2017.

Idn Time, 10 Potret Kajian Musawarah, Kelompok Pengajian Artis Hijrah, diakses di laman https://www.idntimes.com/hype/entertainment/ika-pratiwi-1/potretkajian-musawarah-kelompok-pengajian-artis-hijrah-hp-c1c2-1, $01 \quad$ Oktober 2019.

Instagram Kajian MuSaWaRah https://www.instagram.com/kajianmusawarah/

Instagram Arie Untung (@ariekuntung)

Twitter Nadirsyah Hosen (@na_dirs)

Youtube channel Al-Muwatta

Youtube channel Kajian Musawarah 